\title{
Correspondence
}

CHI. \& WTO ReV. 2016:2; 361-368

http://dx.doi.org/10.14330/cwr.2016.2.2.09

pISSN 2383-8221 • elSSN 2384-4388

China and WTO Review

\section{Obama, WTO Trade Enforcement, and China*}

\author{
Stuart S. Malawer ${ }^{* *}$
}

\section{Introduction}

Since US President Obama entered office in 2009, his administration filed 20 WTO cases and won every one that was decided. ${ }^{1}$ At the time of this assertion, there were 11 filings against China. The cases filed against China that have been won by the US have concerned, among others: Chinese duties or restrictions on the US high-tech steel exports; ${ }^{2}$ violation of intellectual property rights; ${ }^{3}$ dumping of Chinese tires into the US marketplace; ${ }^{4}$ restrictions on imports of autos into China; ${ }^{5}$ and restricted use of electronic payment systems (credit cards) in China. ${ }^{6}$ It also involved Chinese restrictions on exports of rare Earth elements ${ }^{7}$ and other raw materials from China. ${ }^{8}$

\section{Recent US - China Litigation in the WTO.}

This certainly sounds like a great achievement for the US trade enforcement that would reflect a sterling record in the WTO dispute resolution system. But is it a great achievement? It might be, but the whole story is much more nuanced and important to understand. The Obama administration does not point out that China

* An abbreviated version of this article was printed as an Op-Ed in the Richmond Times-Dispatch (June 19, 2016).

** Distinguished Service Professor of Law and International Trade at George Mason University Schar School of Policy and Government. J.D. (Cornell), M.A./Ph.D.(UPenn), Diploma (Hague Academy of Int'l Law). Dr. Malawer is the author of WTO LAw, Litigation \& Policy (William S. Hein \& Co., 2007). The author may be contacted at: StuartMalawer@msn.com 
has prevailed in a number of cases against the US.

Take, e.g., the 2012 case decided against the US that involved the use of 'zeroing' as a method for calculating antidumping duties. ${ }^{9}$ Another case was decided in 2014 against the US regarding its application of non-market status in calculating dumping and countervailing duties for certain Chinese imports. ${ }^{10}$ Yet, another case decided in 2015 involved the wrongful determination that a state-owned enterprise is a public body and thus capable of providing illegal government subsidies." Indeed, just in May 2016, China requested a compliance procedure against the US for its failure to implement a decision involving countervailing duties on Chinese exports by state-owned enterprises. ${ }^{12}$

Newer cases that have been brought by the US are pending and involve Chinese taxation on aircraft ${ }^{13}$ and 'demonstration bases' (special manufacturing zones) that seem to be in the process of settling before litigation. ${ }^{14}$ Both involve issues of subsidies. The 12th and 13th cases against China were filed this June and July by the Obama administration. They involve Chinese compliance with a prior decision regarding the dumping and countervailing duties imposed on the import of the US broiler chickens ${ }^{15}$ and Chinese export restrictions on nine minerals. ${ }^{16}$ The only other compliance case ever filed by a WTO member was also filed by the US, and it was decided in 2015. ${ }^{17}$ As recently observed: "It is becoming clear that the US and its geopolitical rival are already skirmishing ahead of what could be a combative summer."

Perhaps the most important metric to look at when determining a member's compliance with the WTO's decisions is whether it has authorized sanctions against a country for not implementing its panel or Appellate Body recommendations. Surprisingly, it is not China but the US that holds the honor of being sanctioned the most. China has never been sanctioned. No such sanctions have ever been authorized in the US-China disputes.

E.g., the US was sanctioned in 2015 for not complying with the "Country of Origin Labeling" ("COOL") requirements in two cases brought by Canada and Mexico concerning the import of beef and pork. ${ }^{19}$ The US rules required the identification of the foreign source of imports, which violates the WTO rules.

An examination of the most recent WTO report on sanctions covers its first 20 years $(1995-2014) .{ }^{20}$ It indicates that sanctions were authorized against the United States in three distinct cases involving the use of foreign sale corporations, 
cotton subsidies, and restrictions on online betting services. These cases involved multiple complaining parties. The US has been sanctioned more than any other country.

It is interesting to put all of this in a slightly broader context. In the 25 -year history of the WTO, over 500 trade disputes have been submitted. The dispute settlement system experienced its busiest year in 2015, with an average of 30 active panels per month. ${ }^{21}$ Most of the referred requests involved trade remedy issues regarding dumping, subsidies, and safeguards, among others.

The US is the leading user of the WTO Dispute Settlement Body, ${ }^{22}$ though many countries use it. Developing countries now file about one-half of the cases each year. Out of the 500 cases filed, only about one-third of them wind up in full litigation before a panel. Most are settled in the diplomatic consultation stage that precedes the panel hearing. The US has won the vast number of cases it litigated in the WTO as both a complainant and respondent. There have only been a handful of requests for sanctions, and even fewer have been authorized. However, perhaps only three or four of those requests for sanctions were implemented, which is not much.

The US has filed more cases against China than any other country. Interestingly, China has tended to promptly implement all adverse decisions that the US has secured against it. The Obama administration has generally been very active in the WTO litigation and successful in those cases against China specifically. However, the US has also lost a number of cases brought against it by China. Of course, the administration does not normally broadcast this. The US is the country against which sanctions have been authorized the most, though only a few times. China has implemented the adverse decisions of the WTO. This should be noted more by the administration, since it shows a positive aspect of China's engagement in the global trading system and its acceptance of and role in developing rules of the road.

\section{Conclusion}

My general conclusion is that the Obama administration is correct in broadly stating its success in the WTO litigation in general as well as against China. In terms of full disclosure, however, the US has taken some unsettling actions, 
namely not fully discussing its losses to China, China's general compliance, and sanctions that have been authorized against it. The recent US opposition to reappointing a Korean judge to the Appellate Body because of his decisions concerning the US trade remedy laws is disappointing. ${ }^{23}$

My take is that as the primary architect of the WTO, its dispute resolution system, and judicial and rules-based approach to global trade relations, the US should be a bit more careful and supportive so as not to undermine this system. In particular, the US should promptly implement decisions made against it.

In a lead editorial, FinANCIAL TIMES recently stated: "The problem is not just that the (trade remedy) rules are often arbitrary and skewed - the US has rightly lost case after case at the World Trade Organization over the way it imposes such tariffs .... ${ }^{24}$ Indeed, a few days earlier, another article in FinAnCial Times concluded:

The US has spent years to defend indefensible rules governing the imposition of antidumping and countervailing duties on imports.... In 2014 ... Washington finally admitted (after losing a case brought by Brazil concerning cotton support programs) it could not bring itself to cut the handouts to its own farmers....

Most recently, Financial Times concluded once again: "In the case of the US, while the legalistic nature of its antidumping regime will not change, the administration could at least give up trying to defend its more egregious aspects from legal challenge in the WTO." ${ }^{26}$

The system has served the US national interests well in resolving trade disputes in general and those between the US and China. It is not the absence of litigation that makes a system successful. Rather, it is how the cases are resolved when commercial disputes arise, as they do when more international commercial transactions occur. So far, they have been successfully resolved within the system.

Hopefully, the judicial and diplomatic approach developed in the WTO can be expanded to apply to non-commercial disputes between China and the US. After all, the commercial and political relationships between China and the US are critically interrelated. They are the most important as the 21 st century rolls along.

The Obama administration should be proud of its strategy in the WTO generally and its enforcement of actions against China, but there is no need to puff it up. A realistic assessment would analyze both the US' and China's losses 
as well as sanctions by other countries against the US. It would more accurately describe a complex system and make this unique international legal system look more balanced. This stance would give the US policymakers the opportunity to further the global trading system in a more realistic manner.

Trade enforcement strategy is an important trade as well as foreign policy issue. Above all else, it has huge geopolitical implications for the US national security. This is especially true in the context of the US-China relations.

\section{REFERENCES}

1. See Enforcement, available at https://ustr.gov/issue-areas/enforcement (last visited on June 13, 2016).

2. China-Countervailing and Antidumping Duties on Grain Oriented Flat-Rolled Electrical Steel (GOES) from the United States, WT/DS414/RW (Compliance report, July 31, 2015), available at https://docs.wto.org/dol2fe/Pages/FE_Search/FE_S_S009-DP.aspx?language $=$ E\&CatalogueIdList $=133668,133660 \&$ CurrentCatalogueIdIndex $=0 \&$ FullTextHash $=$ (last visited July 31,2016$)$. This compliance proceeding was the first time any WTO member challenged China's compliance with an adverse finding.

3. China-Measures Affecting the Protection and Enforcement of Intellectual Property Rights, WT/DS362/R (Panel report, Jan. 26, 2009), available at https://www.wto.org/english/tratop_ e/dispu_e/cases_e/ds362_e.htm (last visited on July 23, 2016).

4. United States-Measures Affecting Imports of Certain Passenger Vehicle and Light Truck Tyres from China, WT/DS399/AB/R (AB report, Oct. 5, 2011), available at https://www.wto. org/english/tratop_e/dispu_e/cases_e/ds399_e.htm (last visited on July 23, 2016).

5. China-Anti-Dumping and Countervailing Duties on Certain Automobiles from the United States, WT/DS440/R (Panel report, May 23, 2014), available at https://www.wto.org/english/ tratop_e/dispu_e/cases_e/ds440_e.htm (last visited on July 23, 2016).

6. China-Certain Measures Affecting Electronic Payment Services, WT/DS413/R (Panel report, July 16, 2012), available at https://www.wto.org/english/tratop_e/dispu_e/cases_e/ds413_ e.htm (last visited on July 23, 2016).

7. China-Measures Related to the Exportation of Rare Earth, Tungsten and Molybdenum, WT/ DS431/AB/R (AB report, Aug. 29, 2014), available at https://www.wto.org/english/tratop_e/ dispu_e/cases_e/ds431_e.htm (last visited on July 23, 2016).

8. China-Measures Related to the Exportation of Various Raw Materials, WT/DS394/AB/R (AB report, Jan. 30, 2012), available at https://www.wto.org/english/tratop_e/dispu_e/cases_e/ ds394_e.htm (last visited on July 23, 2016).

9. United States-Anti-Dumping Measures on Shrimp and Diamond Sawblades from China, WT/ 
DS422/R (Panel report, June 8 2012), available at https://www.wto.org/english/tratop_e/ dispu_e/cases_e/ds422_e.htm (last visited on July 23, 2016).

10. United States-Countervailing and Anti-Dumping Measures on Certain Products from China, WT/DS449/AB/R (AB report, July 22, 2014), available at https://www.wto.org/english/ tratop_e/dispu_e/449abr_e.pdf (last visited on July 23, 2016).

11. United States-Countervailing Duty Measure on Certain Products from China, WT/DS437/ $\mathrm{AB} / \mathrm{R}$ (AB report, Jan. 16, 2015), available at https:/www.wto.org/english/tratop_e/dispu_ e/cases_e/ds437_e.htm (last visited on July 23, 2016).

12. China Requests Consultations with US over Compliance in Countervailing Duties Dispute, WTO News (May 13, 2016), available at https://www.wto.org/english/news_e/news16_e/ ds437oth_13may16_e.htm (last visited on July 23, 2016).

13. China-Tax Measures concerning Certain Domestically Produced Aircraft, WT/DS501/1 (Request for consultation, Dec. 8, 2015), available at https://www.wto.org/english/tratop_e/ dispu_e/cases_e/ds501_e.htm (last visited on July 23, 2016).

14. China-Measures Related to Demonstration Bases and Common Service Platforms Programmes, WT/DS489/1 (Request for consultation, Feb. 11, 2015), available at https:// www.wto.org/english/tratop_e/dispu_e/cases_e/ds489_e.htm (last visited on July 23, 2016).

15. China-Antidumping and Countervailing Duty Measures on Broiler Products from the United States, WT/DS427/1 (Compliance proceedings ongoing June 22, 2016), available at https://www.wto.org/english/tratop_e/dispu_e/cases_e/ds427_e.htm See also The United States Challenges China's Non-Compliance at the WTO on Behalf of American Farmers, USTR Press Release (May 19, 2016), available at https:/ustr.gov/about-us/policy-offices/ press-office/press-releases/2016/may/us-challenges-china-non-compliance-at-WTO (all last visited on July 23, 2016).

16. China-Export Duties on Certain Raw Materials, WT/DS508/1/Add.1 (Request for Consultation by the US, July 13, 2016), available at https://www.wto.org/english/tratop e/dispu_e/cases_e/ds508_e.htm. See also S Donnan, Obama Steps up Trade Battle with China, Fin. Times, July 13, 2016, available at http://www.ft.com/cms/s/0/fed9f136-491411e6-8d68-72e9211e86ab.html\#axzz4FLAZbXsH (all last visited on July 24, 2016). It reads: "Barack Obama has escalated the US's trade battle with China, launching a formal complaint against Beijing as both of his potential successors push the domestic political debate in a protectionist direction on the campaign trail." "Obama Launches Trade Complaint amid Growing Tension with China."

17. Supra note 2 . The only other compliance case ever filed by a WTO member against China was also filed by the US, and it was decided in 2015.

18. S. Donnan, US and China Skirmish as Trade Clash Looms, Fin. Times, Mar. 11, 2016, available at https://next.ft.com/content/4bd8c6ec-16c5-11e6-b8d5-4c1fcdbe169f (last visited on July 23, 2016).

19. United States-Certain Country of Origin Labelling (COOL) Requirements, WT/DS384 
(Authorization to retaliate, Dec. 21, 2015), available at https://www.wto.org/english/tratop_ e/dispu_e/cases_e/ds384_e.htm (last visited on July 23, 2016).

20. Overview of the State of Play of WTO Disputes (Section IV: Recourse to Article 22), in 2014 Annual Report of the Dispute Settlement Body of the WTO, WT/DSB/64/Add.1 (Nov. 26, 2014), available at $\mathrm{https}$ //docs.wto.org/dol2fe/Pages/FE_Search/FE_S_S009-DP.aspx?lang uage $=$ E \&CatalogueIdList $=128838,120508,92133,99233,107504,102197,94202,70311,5877$ $7,51691 \&$ CurrentCatalogueIdIndex $=0 \&$ FullTextHash $=$ (last visited on July 23, 2016).

21. Chapter-Dispute Settlement Activity in 2015, 2016 WTO Annual Report, available at https:// www.wto.org/english/res_e/booksp_e/anrep_e/anrep16_chap6_e.pdf (last visited on July 23, 2016).

22. S. Malawer, U.S.-China Trade Relations - Litigation in the WTO 2001-2014, 27 International Law Practicum (2014), available at http:/globaltraderelations.net/images/ Malawer.U.S._-_CHINA_LITIGATION_IN_THE_WTO_2001-2014_NYSBA, International_Law_Practicum_Spring_2014_.pdf(last visited on July 23, 2016).

23. See Washington Threatens to Undermine the WTO, Fin. Times, May 31, 2016, available at http://www.ft.com/cms/s/0/e679fd58-2730-11e6-8b18-91555f2f4fde. html\#axzz4FBRKXCte (last visited on July 23, 2016). It reads: "Washington has taken the unusual step of blocking the reappointment of Seung Wha Chang ...."

24. Lead Editorial, Coping with a World of Too Much Chinese Steel, Fin. Times, June 10, 2016, available at http://www.ft.com/intl/cms/s/0/6a9391d4-2e3a-11e6-a18d-a96ab29e3c95. html\#axzz4FBRKXCte (last visited on July 23, 2016).

25. Supra note 23.

26. Lead Editorial, Protectionism May Bark but Still Has No Bite, Fin. Times, June 24, 2016, available at https://next.ft.com/content/b163ce90-3942-11e6-9a05-82a9b15a8ee7 (last visited on July 23, 2016). 
